\title{
Body and testicular biometry of Crioulo stallions
}

\section{Fernanda Carlini Cunha dos Santos $^{1 *}$ (i) Bruna da Rosa Curcio ${ }^{(1)}$ Carlos Eduardo Wayne Nogueira ${ }^{2}$ (i)}

${ }^{1}$ Departamento de Medicina Veterinária, Universidade Federal de Roraima (UFRR), 69310-970, Boa Vista, RR, Brasil. E-mail: carlini.fernanda@hotmail.com. ${ }^{*}$ Corresponding author.

${ }^{2}$ Departamento de Clínicas Veterinária, Faculdade de Veterinária (FV), Universidade Federal de Pelotas (UFPel), Pelotas, RS, Brasil.

ABSTRACT: Brazilian Association of Crioulo Horse Breeders (ABCCC) establishes minimal and maximal body biometrics evaluation; although, nothing is mentioned about testicular measurements. Body and testicular growth are associated and related to age. We described data regarding body and testicular biometry of Crioulo stallions, with a comparative study between young and adult categories. Evaluation was performed in 56 stallions, Crioulo breed, split in: youngsters (3 and 4 years-old, $n=16)$ and adults (above 5 years-old, $n=40)$. Body biometry included weight, height, cannon bone and chest circumference, body score condition and neck fat accumulation. Testicular biometry included height, length, width, volume, combined volume and daily sperm output (DSO). Statistical analyses included descriptive statistic, Pearson correlation, comparison between means by Kruskal Wallis, being $P<0.05$ considered significant. There was no significant difference between the parameters of body and testicular biometrics between categories young and adult. In relation to height, the average was very close to the lower limit established, while chest and cannon bone circumference were above the minimum recommended by ABCCC. Cannon bone circumference presented a positive correlation with height. Most of stallions presented excessive body fat, with a body score condition above 8 (scale 1-9). Neck fat accumulation presented a positive correlation with body score condition. Testicular height, length, width and volume presented a positive correlation between the ipsi and contralateral testicle, total testicular volume and DSO. In conclusion, no difference in the body and testicular biometric evaluation was observed between young and adult Crioulo stallions. Testicular and body growth are associated and also related to age, so our finding suggested that after 3-4 years-old most of Crioulo stallions have already reached maximum growth. Key words: growing, foal development, puberty, morphology, morphometry.

Biometria corporal e testicular de garanhões da raça Crioula

RESUMO: A Associação Brasileira de Criadores de Cavalos Crioulos (ABCCC) define parâmetros mínimos e máximos para algumas aferições biométricas no corpo do animal, embora nada seja mencionado sobre medidas testiculares. O crescimento corporal e testicular estão associados e relacionados a idade do animal. Objetivamos descrever parâmetros relacionados a biometria corporal e testicular de garanhões Crioulos, comparando o grupo de jovens e adultos. Foi realizada avaliação em 56 garanhões Crioulos, divididos em: jovens (três e quatro anos, $n=16$ ) e adultos (acima de cinco anos, $n=40$ ). A biometria corporal incluiu peso, altura, circunferência de canela, perímetro torácico, escore corporal e acúmulo de gordura no pescoço. A biometria testicular incluiu altura, comprimento, largura, volume de cada testículo, volume combinado dos testículos e estimativa de produção diária de espermatozoides (DSO). Com os dados, foi realizada estatística descritiva, correlação de Pearson, comparação entre médias com Kruskal Wallis, sendo considerado significativo quando P < 0,05. Não foi observada diferença significativa entre as avaliações biométricas e testiculares de garanhões das categorias jovens e adultos. Em relação à altura, a média foi muito próxima ao limite inferior estabelecido, enquanto a circunferência torácica e de canela estavam acima do limite mínimo recomendado pela ABCCC. A circunferência de canela apresentou correlação positiva com altura. A maioria dos garanhões apresentou alta deposição de gordura, com condição corporal acima de 8 (escala 1-9). O acúmulo de gordura no pescoço apresentou correlação positiva com escore corporal. A altura, largura, comprimento e volume testicular apresentaram correlação positiva com testículo ipsi e contralateral, volume testicular total e DSO. Em conclusão, não houve diferença entre dados de biometria corporal e testicular de garanhões Crioulos adultos e jovens. O crescimento corporal e testicular estão associados e relacionados a idade, sendo assim, nossos resultados sugerem que após 3-4 anos de idade, a maioria dos garanhões Crioulos já atingiu seu pico de desenvolvimento.

Palavras-chave: desenvolvimento de potros, crescimento, morfologia, morfometria, puberdade.

\section{INTRODUCTION}

The Crioulo horse of southern Latin America is a direct descendant of the horses brought to the New World by the Spanish and Portuguese conquers, during the sixteenth century (RODERO et al., 1992). This breed is a descendant of native horse from those territories, being originated from Equus caballus asiaticus, which also originated Arabian breed, and Equus caballus africanus. In Brazil, 
many of these animals escaped or were abandoned, reproducing freely in herds, returning to a wild state and being submitted to natural selection.

The main characteristics inherited from their ancestors are average height; short, triangular, straight or subconvex head; short, well-separated ears, broad at the base, raised neck, slightly sloping rump, abundance of horsehair and tail and active temperament (ABCCC, 2020). The Crioulo horse has morphological, functional and behavioral characteristics inherent to the breed. The selection methods currently used in reproduction farms are subjective, based on the owners' experience and personal preferences. Also, mares and stallions, which won competitions, are elected to become breeders.

Regarding body biometry, measures adopted by Brazilian Association of Crioulo Horse Breeders (Associação Brasileira de Criadores de Cavalos Crioulos - ABCCC) for males are: height between 140-150 cm; minimum chest circumference of $168 \mathrm{~cm}$; minimum cannon bone circumference of $18 \mathrm{~cm}$. For females the measures are height between $138-150 \mathrm{~cm}$; minimum chest circumference of 170 $\mathrm{cm}$; minimum cannon bone circumference of $17 \mathrm{~cm}$.

Regarding testicular biometry, the amount of sperm that a stallion produces varies according to the amount of functional testicular tissue, which is correlated with testicular size. Measurement of testicular size is an important factor, considering the selection and management of breeders aiming maximum reproductive efficiency (GEBAUER et al., 1974; PICKETT, 1993; SUDA et al., 1992).

According to ABCCC, from 2001 until the end of 2010 there was an increase of 143.7 percent in applications for registration of temporary records, jumping from 10.271 in 2001 to 25.020 in 2010. Based on this growth, the Association estimates that this number could reach 57.502 in the year 2020, an increase of approximately 129.82 percent over 2010 .

Growing expansion and appreciation of Crioulo breed encourages scientific research in the area, since this activity has a significant economic impact in Brazil. However, currently there are still few studies describing the biometric characteristics of Crioulo stallions. Considering this situation, this research aimed to describe data related to body and testicular biometrics of Crioulo stallions, comparing young and adults.

\section{MATERIALS AND METHODS}

Body and testicular biometrics were evaluated in 56 Crioulo stallions, located in the state of Rio Grande do Sul (RS), Brazil. Age of the animals was obtained in the Genealogical Registration section of ABCCC, ranging between 3-18 years. The animals were classified as young, between $3-4$ years $(n=16)$ and adults, above 5 years $(\mathrm{n}=40)$.

All stallions had the ABCCC mark on the right hind limb. This mark means that the stallion is within the reference body measures (height, chest and cannon bone circumference) and morphological features adopted by ABCCC; consequently, able to be used as breeders.

Body biometrics was assessed with a measuring tape, weight tape, hypometer and ultrasound, including: Weight (circumference measured with a weight tape positioned just after the withers end); Height (distance between the ground and the height at the withers, measured with a hypometer); Cannon bone circumference (circumference of the left thoracic limb in the metacarpus middle third); Chest circumference (circumference measurement using a tape positioned just after the end of the withers); Body condition score (ECC - scale of 1-9 by visualization and palpation, according to Henneke Chart scale); Neck fat (measurement of subcutaneous fat at the neck crest by ultrasound, with a linear transducer and a frequency of $5 \mathrm{mHz}$ ).

Testicular biometry was measured with a pachymeter, in the left and right testicles, being evaluated: Width (distance between the lateral and the medial side); Height (distance between the dorsal and the ventral surfaces); Length (distance between cranial and caudal pole); Testicular volume (width $\mathrm{x}$ height $x$ length $x$ 0.5333); Combined testicular volume (right testicular volume + left testicular volume); Daily sperm output (DSO) [(combined testicular volume * 0.024) - 0.76], as described by LOVE et al., (1991), which estimates sperm production $\times 10^{9}$.

Descriptive statistical analysis (minimum, maximum, average and standard error of the mean) of variables were performed, as well as normality test, comparison of means by Kruskal Wallis and Pearson's correlation. Tests were executed with Statistix $9^{\circledR}$ (Statistix, Statistix 9 for Windows, Analytical Software, Tallahassee, FL, USA, 2008), being $\mathrm{P}<0.05$ considered significant.

\section{RESULTS AND DISCUSSION}

In body biometry data, there was no difference between young and adult stallions (Table 1). In the present study, only animals from 3 years old (after the end of the growth phase) were included and; consequently, animals that had already reached their 
Table 1 - Average \pm standard error mean (SEM) of Crioulo stallions body biometry.

\begin{tabular}{lcc}
\hline Body biometry & Young $(\mathrm{n}=16)$ & Adult $(\mathrm{n}=40)$ \\
\hline Height $(\mathrm{cm})$ & $141.1 \pm 2.3$ & $141.4 \pm 0.4$ \\
Weight $(\mathrm{kg})$ & $449.4 \pm 11.5$ & $421.7 \pm 7$ \\
Chest circunference $(\mathrm{cm})$ & $179.4 \pm 4.3$ & $175.7 \pm 4.2$ \\
Cannon bone circunference $(\mathrm{cm})$ & $19 \pm 0.2$ & $19.2 \pm 0.1$ \\
ECC (scale 1-9) & $7.4 \pm 1.2$ & $7.4 \pm 0.1$ \\
Neck fat $(\mathrm{cm})$ & $9.4 \pm 0.1$ & $8.7 \pm 0.4$ \\
\hline
\end{tabular}

${ }^{*}$ No statistical difference was observed between young and adult.

Young: 3-4 years-old.

Adult: 5 or more years-old.

ECC: body score condition.

maximum growth and height. In Crioulo breed horses, PIMENTEL et al. (2017) reported that immediately after birth the foal has $62.14 \%$ of the adult height; at 12 months about $89.28 \%$; at 24 months $95.71 \%$; and at 36 months $98.57 \%$.

The average height was close to the lower limit (141.3 cm young and $141.4 \mathrm{~cm}$ adults) recommended by ABCCC (minimum 140 and maximum $150 \mathrm{~cm})$. However $10.7 \%$ (6/56) of stallions were $138 \mathrm{~cm}$ tall at the time of the evaluation. These data corroborate with those reported in the literature, by KURTZ FILHO and LÖF (2007), where the authors reported that males $(n=866$, age $2-13$ years) had an average height close to the minimum limit and attributed this finding to the probable use of ascendants with short stature. In some countries, such as Chile, this characteristic is attributed to greater racial purity and adaptation to national equestrian events (FCCC, 2020).

Regarding the chest circumference, mean values (179.9 cm young and $175.7 \mathrm{~cm}$ adults) were above the minimum recommended by the breed association $(168 \mathrm{~cm})$. The thoracic perimeter showed a positive correlation with ECC and weight. As reported by KURTZ FILHO \& LÖF (2007), average thoracic perimeter of horses in an agricultural show was $179 \mathrm{~cm}(\mathrm{n}=866$, age 2-13 years), with a minimum value of 168 and a maximum of $196 \mathrm{~cm}$.

Regarding cannon bone circumference, all stallions showed values equal or greater $(19 \mathrm{~cm}$ young and $19.2 \mathrm{~cm}$ adults) than recommended by the breed association $(18 \mathrm{~cm})$. The cannon bone circumference showed a positive correlation with height. Similar results have been reported in the literature, by
KURTZ FILHO \& LÖF (2007), with a mean cannon bone perimeter of $20 \mathrm{~cm}$ and an amplitude of 18-22 $\mathrm{cm}(\mathrm{n}=866$, age $2-13$ years $)$.

In the group of young horses, all of them were kept most of the time in stables, in intensive management, in preparation for morphological exhibitions or sports competitions. In the group of adults, most of the stallions were in a semi-extensive management, being kept in stables during the night and released in paddocks during the day. In youngster, average weight (449 $\mathrm{kg}$ ) and neck accumulated fat $(9.4 \mathrm{~cm})$ were higher than in adults $(421 \mathrm{~kg}$ and 8.7 $\mathrm{cm}$, respectively) $(\mathrm{P}>0.05)$. This finding can be attributed to the intense preparation for morphological exhibitions, especially in young animals. Neck fat showed a positive correlation with ECC. Overweight associated with physical exercise increases the risk of musculoskeletal injuries, in addition to these, those are stressful for the joints (MCILWRAITH, 2004). Fat accumulation can cause chronic inflammatory process that affects the entire organism, including joints, muscles, hooves, liver, pancreas, uterus and testicles. Consequently, fat accumulation predisposes to numerous clinical-metabolical problems (FRANK, 2009), being undesirable considering the animal's general health.

Body score assessment in horses is a simple and easy method that is used to estimate and monitor body fat accumulation. In mares, this parameter is related to reproductive efficiency, including estrous cycle duration, conception rate, interval between births, duration of pregnancy and embryonic losses (HENNEKE et al., 1983). About 34\% (19/56) of the evaluated stallions had a body score condition below or equal to 7 and $66 \%(37 / 56)$ had a body score 
between 8 and 9. Therefore, most animals had excess of fat at the time of assessment. In humans, obesity is associated with subfertility and infertility, due to changes in sperm quality parameters (DU PLESSIS et al., 2010). In ruminants, a high body score impairs sperm quality. However, no difference was observed between sperm parameters after thawing of semen from Crioulo stallions, with low or high body score, suggesting that only the assessment of body fat is not able to explain sperm quality after thawing (NOVELLO et al., 2020).

Data regarding testicular biometry are shown in table 2. Among the parameters evaluated, there was no significant difference between the linear measurements of right and left testicles, similar to that described in the literature by GREGORY (2013) and MENDES (2012) in Crioulo horses; by BORGES et al. (2010), PARLEVLIET et al. (1994) and WADDINGTON et al., (2017) in other breeds. Testicular height, length, width and volume showed a positive correlation between ipsi and contralateral testis, testicular volume and DSO.

Testicular growth occurs gradually and proportional to body growth from the 12th month of life until puberty (NADEN et al., 1990). In Crioulos foals, the first epididymal sperm was reported at 16 months of age, when the testicular volume reached 16 $\mathrm{cm}^{3}$ and testicular weight of 23 grams (GREGORY, 2013). The number of Sertoli cells, weight and testicular size increase with age, stabilizing when the stallion reaches sexual maturity, about 4-5 years in most breeds (THOMPSON, 1979). In the present study, no difference was reported between testicular biometric data between young and adult horses. Corroborating with the literature, these findings suggest that after 3-4 years of age, testicular measurements have little variation, considering that they have already reached their maximum growth size.

About testicular biometry, there are no data with minimum and maximum values recommended by the breed association (ABCCC). Corroborating with Mendes (2012), biometric evaluation of Crioulo horses over 3 years of age $(n=19)$ showed similar values to the ones reported in our study, being TE width $(48.2 \pm 1.9)$, TE length $(82.8 \pm 2.6)$, TE height (44.4 \pm 2.0$)$, TD width $(49.2 \pm 1.9)$, TD length $(85.2$ $\pm 2.0)$ and TD height $(43.8 \pm 1.9)$, in millimeters (MENDES, 2012).

Considering other breeds, values of testicular biometry of Crioulo stallions are lower than those reported for Campolina (BORGES et al., 2010; MANSO FILHO et al., 2000) and Mangalarga Marchador (CRUZ et al., 2009; WADDINGTON et al., 2017). The Crioulo breed is considered small to medium sized, while the other reported breeds are considered medium to large sized. Therefore, it is believed that testicular size of Crioulo stallions could be related to breed size, with no reduction in fertility and/or sperm production capacity. All stallions included in the present study were used in the last breeding season with proven in vivo fertility.

The variation existing in the mean of testicular measurements between breeds has already been attributed to different sizes, especially when

Table 2 - Average \pm standard error mean (SEM) of Crioulo stallions testicular biometry.

\begin{tabular}{lcc}
\hline Testicular biometry & Young $(\mathrm{n}=16)$ & Adult $(\mathrm{n}=40)$ \\
\hline Height LT $(\mathrm{cm})$ & $5.3 \pm 0.1$ & $5.4 \pm 0.1$ \\
Width LT $(\mathrm{cm})$ & $4.7 \pm 0.2$ & $4.4 \pm 0.1$ \\
Lenght LT $(\mathrm{cm})$ & $8 \pm 0.3$ & $7.9 \pm 0.1$ \\
Volume TE $\left(\mathrm{cm}^{3}\right)$ & $110 \pm 10.8$ & $103.3 \pm 6.6$ \\
Height RT $(\mathrm{cm})$ & $5.7 \pm 0.2$ & $5.5 \pm 0.1$ \\
Width RT $(\mathrm{cm})$ & $4.6 \pm 0.1$ & $4.6 \pm 0.1$ \\
Lenght RT $(\mathrm{cm})$ & $7.6 \pm 0.3$ & $7.7 \pm 0.2$ \\
Volume TD $\left(\mathrm{cm}^{3}\right)$ & $107 \pm 8.1$ & $100 \pm 14.3$ \\
Testicular combined volume $\left(\mathrm{cm}^{3}\right)$ & $218 \pm 16$ & $210 \pm 13$ \\
DSO $\left(\mathrm{x} 10^{9}\right)$ & $4.4 \pm 0.3$ & $4.4 \pm 0.2$ \\
\hline
\end{tabular}

*No statistical difference was observed between young and adult.

Young: 3-4 years-old.

Adult: 5 or more years-old.

LT: left testicle; RT: right testicle; DSO: daily sperm output. 
these measurements are measured in equine ponies (PACCAMONTI et al., 1999). In addition, the minimum total testicular width for stallions should be $8 \mathrm{~cm}$, according to PICKETT (1993); although, it is not specified about the breed or size of the animal.

According to CBRA (2013), in adult horses scrotal width cannot be less than $7 \mathrm{~cm}$. In our study, all stallions had a total testicular width above this value $(9.3 \mathrm{~cm}$ young and $9 \mathrm{~cm}$ adults $)$. In addition, a testicular biometric pattern may exist among horses ranging between individuals of the same breed (FONSECA et al., 1997), with testicular size influenced by genetic inheritance, body score, feeding, age, among other factors.

Volume is a combination of linear testicle measurements (height, length and width) being this parameter used to suggest stallions with high or low reproductive potential. In dogs (OLAR, 1983), bulls (FRENEAU, 2006) and horses (LOVE et al., 1991) the largest testicular size coincided with the largest number of sperm produced and ejaculated. The testicular size and weight of the parenchyma are correlated with daily sperm production, being a parameter for predicting a stallion's reproductive potential (CHENIER, 2007).

Testicles size can be used to calculate the estimated number of sperm available in the ejaculation, which indirectly allows estimating daily sperm production (PICKETT \& VOSS 1998). As testicular volume increases, the number of sperm in the ejaculate also increases (CLAY \& CLAY, 1992), considering healthy animals. In stallions, DSO is between 4 to $6 \times 10^{9}$ spermatozoa/ejaculate/ day; however, this parameter is greatly influenced by the animal's age and season (HURTGEN, 1992), in addition to individual characteristics. In the present study, both young and adult stallions showed an average daily sperm production of $4.4 \times 10^{9}$, being within the limits described in the literature (HURTGEN, 1992). Calculation of DSO uses only linear measurements of the testis, obtained by direct measurement or with ultrasound. Testicular biometrics can be easily included during breeding soundness examination of the stallion. Theses measurements associated with sperm quality evaluation help to predict the stallion's reproductive potential. However, the depletion of extragonal sperm reserves, followed by breeding soundness exam, allows a better understanding of sperm quality and production of each individual. Consequently, the results of this evaluation help to adjust the individual's reproductive management, maximizing the use of the stallion, during breeding season.

\section{CONCLUSION}

Body and testicular biometry presented no difference between young ( 3 and 4 years old) and adults (over 5 years old) Crioulo stallions. Since testicular and body growth are associated and related to age, our finding suggests that after 3-4 years of age most of Crioulo stallions have already reached their maximum growth size.

\section{BIOETHICS AND BIOSSECURITY COMMITTEE APPROVAL}

This experiment used animals in the experimental model and had the approval of the Institutional Research Ethics Committee of Universidade Federal de Pelotas (UFPel), Pelotas, Rio Grande do Sul, Brazil, by the number CEEA-9893-2014.

\section{DECLARATION OF CONFLICT OF INTEREST}

The authors report no conflicts of interest. The authors alone are responsible for the content and writing of the paper.

\section{ACKNOWLEDGEMENTS}

We are grateful to the Coordenação de Aperfeiçoamento de Pessoal de Nível Superior (Capes), Brasil Finance code 001 for scholarship.

\section{AUTHOR'S CONTRIBUTIONS}

All authors contributed to the development of this research.

\section{REFERENCES}

Associação Brasileira de Criadores de Cavalos Crioulos (ABCCC). 2020. Manual do Criador. Available from: < http:// www.racacrioula.com.br/site/content/entidade/cavalo crioulo. php>. Accessed: Jan. 24, 2020.

BORGES, G. S. et al. Testicular measurements in Campolina stallions. Boletim de Indústria Animal, v.67, p.157-162, 2010. Available from: <http://www.iz.sp.gov.br/bia/index.php/bia/ article/view/1078>. Accessed: Jan. 18, 2020.

CLAY C. M.; CLAY, J. M. Endrocrine and testicular changes associated with season, artificial photoperiod and the peripubertal period in stallion. Veterinary Clinics of North America: Equine Practice, v.8, p.31-56, 1992. Available from: <https://europepmc. org/article/med/1576553>. Accessed: Jan. 18, 2020. doi: 10.1016/ s0749-0739(17)30465-0.

CHENIER, T. S. Anatomy and examination of the normal testicle. In: SAMPER J.C. et al. (Eds). Current Therapy in Equine Reproduction. 2. ed. Saint Louis: Saunders. pp.167-168, 2007.

COLÉGIO BRASILEIRO DE REPRODUÇÃO ANIMAL (CBRA). Manual Para Exame Andrológico de Sêmen Animal. Belo Horizonte: 104p., 2013. 
CRUZ, M. A. B. Testicular measurements in Campolina stallions. Revista Brasileira de Medicina Veterinária, v.31, p.30-34, 2009 Available from: <http://www.iz.sp.gov.br/pdfsbia/1302293828. pdf $>$. Accessed: Jan. 18, 2020

DU PLESSIS, S. S. et al. The effect of obesity on sperm disorders and male infertility. Nature Reviews Urology, v.7, p.153161, 2010. Available from: <https://www.nature.com/articles/ nrurol.2010.6\#: :text $=$ The $\% 20$ results $\% 20$ of $\% 20$ several $\% 20$ studies, incidence $\% 20$ of $\% 20$ male $\% 20$ factor $\% 20$ infertility $>$. Accessed: Jan. 18, 2020.

FEDERACIÓN DE CRIADORES DE CABALLOS CHILENOS (FCCC). 2020. Available from: <http://200.75.0.7/Rodeo/ controlador/controlador/control.jsp?ACCION=general/ general\&SUBACCION=QueEsElS elloDeRaza>. Accessed: Jan 24, 2020.

FONSECA, V. O. et al. Reproductive potencial of Nelore bulls (Bos taurus indicus) mated with a large number of cows. Arquivo Brasileiro de Medicina Veterinária e Zootecnia, v.49, p.5362, 1997. Available from: <https://www.scielo.br/pdf/abmvz/ v56n4/21987.pdf>. Accessed: Jan. 18, 2020

FRANK, N. Equine metabolic syndrome. Journal of Equine Veterinary Science, v.29, p.259-267, 2009. Available from: $<$ https://pubmed.ncbi.nlm.nih.gov/21392655/>. Accessed: Jan. 18, 2020. doi: 10.1016/j.cveq.2010.12.004.

FRENEAU, G. E. et al. Puberty in Nellore bulls raised at pasture in Brazil: body, testicular and seminal characteristics and breeding soundness evaluation. Arquivo Brasileiro de Medicina Veterinária e Zootecnia, v.58, p.1107-1115, 2006. Available from: $<$ https://www. scielo.br/scielo.php?pid=S0102-09352006000600020\&script $=$ sci abstract\&tlng $=\mathrm{pt}>$. Accessed: Jan. 18, 2020.

GEBAUER, M. R., et al. Reproductive physiology of the stallion: daily sperm output ant testicular measurements. Journal of the American Veterinary Medical Association, v.165, p. 711 713, 1974. Available from: <https://pubmed.ncbi.nlm.nih gov/4436138/>. Accessed: Jan. 18, 2020.

GREGORY, J. W. et al. Peri-puberty in male Criollo horses - Testicular development, histology of the seminiferous epithelium and epididymal sperm. Pferdeheilkunde, v.29, p.347-352, 2013. Available from: <https://www.researchgate.net/ publication/287365708_Peri-puberty_in_male_Criollo_horses Testicular development histology of the seminiferous epithelium_and_epididymal_sperm>. Accessed: Jun. 09, 2020. doi: 10.21836/PEM20130302.

HENNEKE, D. R. et al. Relationship between condition score, physical measurement, and body fat percentage in mares. Equine Veterinary Journal, v.15, p.371-372, 1983. Available from: <https://www.paardenwelzijnscheck.nl/app/webroot/files/ ckeditor_files/files/Voeding\%20en $\% 20$ Water/Henneke $\% 20$ et $\% 20$ al.\%20(1983)\%20Relationship\%20between $\% 20$ condition $\% 20$ score $\% 2 \mathrm{C} \% 20$ physical $\% 20$ measurements $\% 20$ and $\% 20$ body $\% 20$ fat $\% 20$ percentage\%20in\%20mares.pdf $>$. Accessed: Jun. 09, 2020 doi: 10.1111/j.2042-3306.1983.tb01826.x.

HURTGEN, J. P. Evaluation of the stallion for breeding soundness. Veterinary Clinics of North America: Equine Practice, v.8, p.149-165, 1992. Available from: <https://pubmed.ncbi.nlm.nih. gov/1576547/>. Accessed: Jan. 18, 2020. doi: 10.1016/s07490739(17)30472-8
KURTZ FILHO, M.; LÖF H. K. Biometric in brazilian Criollo horse breed. Archives of Veterinary Science, v.12, p.47-51, 2007. Available from: <https://revistas.ufpr.br/veterinary/article/ view/9228>. Accessed: Jan. 18, 2020. doi: 10.5380/avs.v12i1.9228.

LOVE, C. C. et al. Evaluation of measures taken by ultrasonography and caliper to estimate testicular volume and predict daily sperm output in the stallion. Journal of Reproduction and Fertility, v.44, p.99-105, 1991. Available from: <https://pubmed.ncbi.nlm. nih.gov/1795307/>. Accessed: Jan. 18, 2020

MANSO FILHO, H. C. et al. Testicular measurements in Campolina stallions. Journal of Equine Veterinary Science, v.20, p.277-278, 2000. Available from: <https://agris.fao.org/agris-search/search. do? recordID=BR2014F01568>. Accessed: Jan. 18, 2020 .

MENDES, L.Q. Aspectos biométricos e histológicos de testículos de garanhões da raça Crioula. 2012. 32f. Dissertação (Mestrado em Medicina Veterinária) - Universidade Federal do Rio Grande do Sul. Available from: <https://lume.ufrgs.br/handle/10183/62121>. Accessed: Jan. 18, 2020

MCILWRAITH, C. W. Developmental orthopedic disease: problems of limbs in young horses. Journal of Equine Veterinary Science, v.24, p.475-479, 2004. Available from: <http://europepmc. org/article/AGR/IND43662943>. Accessed: Jan. 18, 2020. doi: 10.1016/j.jevs.2004.10.004

NADEN, J. et al. Testicular growth, hormone concentrations, seminal characteristics and sexual behaviour in stallions. Journal of Reproduction and Fertility, v.88, p.167-176, 1990. Available from: <https://pubmed.ncbi.nlm.nih.gov/2107299/>. Accessed: Jan. 18, 2020. doi: 10.1530/jrf.0.0880167.

NOVELLO, G. et al. High or low body fat deposition in the presence of a normal oral sugar test is not associated with post-thaw semen parameters in stallions. Journal of Equine Veterinary Science, v.95, p.1-30, 2020. Available from: <https://www.sciencedirect.com/science/ article/abs/pii/S0737080620303622>. Accessed: Jan. 18, 2020

OLAR, T. T. et al. Relationships among testicular size, daily production and output of spermatozoa, and extragonadal spermatozoal reserves of the dog. Biology Reproduction, v.29(5): 1114-1120, 1983. Available from: $<$ https://academic.oup.com/biolreprod/articl e/29/5/1114/2766414?login=true $>$. Accessed: Jan. 18, 2020

PACCAMONTI, D. L. et al. Reproductive parameters of miniature stallions. Theriogenology, v.51, p.1343-1349, 1999. Available from: $<$ https://pubmed.ncbi.nlm.nih.gov/10729098/\#: :text=Average\%20 total $\% 20$ scrotal $\% 20$ width $\% 20$ of, $\% 20$ total $\% 20$ normal $\% 2 \mathrm{C} \% 20$ motile\%20spermatozoa>. Accessed: Jan. 18, 2020. doi: 10.1016/ S0093-691X(99)00078-3.

PARLEVLIET, J. M. et al. Reproductive characteristics and semen quality in maiden Dutch Warmblood stallion. Journal of Reproduction and Fertility, v.101, p.183-187, 1994. Available from: $<$ https://pubmed.ncbi.nlm.nih.gov/8064679/>. Accessed: Jan. 18, 2020. doi: 10.1530/jrf.0.1010183.

PICKETT, B. W. Reproductive evaluation of stallion. In: MCKINNON, A.O. \& VOSS, J.L. (Eds). Equine Reproduction. Philadelfia: Lea \& Feibiger, pp.755-768, 1993.

PICKETT, B. W.; VOSS J. L. Management of shuttle stallion for maximum reproductive efficiency - Part 1. Journal of Equine Veterinary Science, v.18, p.214-224, 1998. Available

Ciência Rural, v.52, n.3, 2022. 
from: <https://www.sciencedirect.com/science/article/abs/pii/ S0737080698801135>. Accessed: Jan. 18, 2020.

PIMENTEL, A. H. et al. Gender on the growth of Criollo foals from birth to three years of age. Ciência Rural, v.47, p.1-6, 2017. Available from: <https://www.scielo.br/j/cr/a/VRBLQkv HMyHhfcXLfvr7kyd/?lang=en>. Accessed: Jun. 09, 2020. doi: $10.1590 / 0103-8478 \mathrm{cr} 20150989$.

RODERO, E. et al. Primitive andalusian livestock and their implications in the discovery of America. Archivos de Zootecnia, v.41, p.383-400, 1992. Available from: <https:/www.researchgate.net/publication/43801304_ Primitive_Andalusian_Livestock_and_their_implication_in_the Discovery_of_America $>$. Accessed: Jan. 18, 2020.

SUDA, Z. et al. The principal component analisys on the histological observation in the testes of young colts. Equine
Research Institute, v.29, p.26-31, 1992. Available from: <https:// agris.fao.org/agris-search/search.do?recordID=JP9401803>. Accessed: Jan. 18, 2020.

THOMPSON, D. L. et al. Testicular measurements and reproductive characteristics in stallions. Journal of Reproduction and Fertility, v.27, p.13-17, 1979. Available from: <https://pubmed.ncbi.nlm.nih.gov/289781/>. Accessed: Jan. 18, 2020 .

WADDINGTON, B. et al. Testosterone serum profile, semen characteristics and testicular biometry of Mangalarga Marchador stallions in a tropical environment. Reproduction in Domestic Animals, v.52, p.335-343, 2017. Available from: <https://www. locus.ufv.br/bitstream/123456789/13193/1/Waddington_et_al2017-Reproduction_in_Domestic_Animals.pdf $>$. Accessed: Jun.

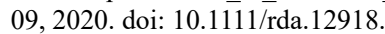

